\title{
Protective antioxidant effect of melanin against chemical burn-induced esophageal injury
}

\author{
Natalia Chornenka*, Yana Raetska, Dmitro Grebinyk, Alevtina Dranitsina, Olexiy Savchuk, Tetiana Beregova, \\ Ludmila Ostapchenko
}

Educational and Scientific Center "Institute of Biology and Medicine" of Taras Shevchenko National University of Kyiv

\section{Correspondence}

Natalia Chornenka, Educational and Scientific Center "Institute of Biology and Medicine" of Taras Shevchenko National University of Kyiv

Email: nata.chornenka24@gmail.com History

- Received: 9 June 2018

- Accepted: 5 September 2018

- Published: 04 October 2018

DOI : 10.15419/bmrat.v5i10.484

\section{Check for updates}

\section{Copyright}

(c) Biomedpress. This is an openaccess article distributed under the terms of the Creative Commons Attribution 4.0 International license.

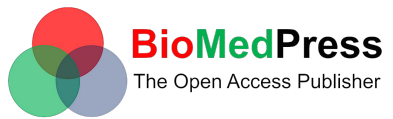

\begin{abstract}
Background: Oxidative stress is the main cause of mortality in chemical burn-induced esophageal injury. Melanin, a natural antioxidant compound from yeast-like fungus Nadsoniella nigra strain X1 , has been shown to decrease the content of lipid peroxidation products after burn. The aim of this study was to investigate the protective effect of melanin in the treatment of esophageal injury after a chemical burn. Methods: A alkali burn model was used to induce injury to the esophagus in immature rats. Changes in the levels of malondialdehyde, secondary products of lipid peroxidation (thiobarbituric acid reactive substances), superoxidase dismutase, and catalase in the blood, as well as changes in the esophagus tissue, were examined. Results: Melanin decreased the content of lipid peroxidation products following burn injury. Melanin increased the activity of superoxidase dismutase and reduced the activity of catalase, as well as reduced esophagus oxidative injury in our chemical burn model. Conclusion: Melanin treatment may protect against chemical burninduced esophageal injury, possibly by inhibiting burn-induced oxidative stress.

Key words: Burn the esophagus, Melanin, Oxidative stress
\end{abstract}

\section{INTRODUCTION}

Esophageal alkaline chemical burns appear to be a serious health problem that lack effective treatment options ${ }^{1}$. The majority of these events occur due to accidental swallowing of alkaline chemicals because of their wide household use. The basic histo-pathologic reaction of a tissue subjected to alkaline burn is collagen synthesis, deposition, and remodeling. In the case of esophageal wall full thickness injuries, the normal esophageal tissues are replaced by dense connective one $^{2}$.

According to statistics, the rate of these burns in Ukraine is 21.3 per 10000 of the population, which corresponds to more than $30 \%$ of all burns received by children under the age of 5 years. In addition, such burns occupy the third place among all types of childhood injuries. Esophagus chemical burn treatment represents one of the most complex specific problems of pediatric medicine, despite all the achievements in this field. Tissue structure immaturity in children, as well as imperfections of vital organ function, are the main cause of prolonged whole organism pathological disorders ${ }^{3}$.

The grave degree of different organ pathological reactions, and varying disease outcomes, are usually dependent on burn injury severity, age of child, and proper therapy selection ${ }^{4}$. Moreover, excessive lipid peroxidation activation is also a factor ${ }^{5}$. As a result of the increased activity of free radical processes and a weakening antioxidant defense (AOD) system, toxic products can accumulate, causing severe metabolic disturbances with general oxidative stress formation ${ }^{6}$. It is already known that activation of lipid peroxide (LP) oxidation (LPO) causes cell membrane oxidative damage, enzyme catalytic activity inhibition, as well as other harmful effects which compromise various vital cell functions ${ }^{7}$. Under the conditions of enhanced LPO processes, the cell's antioxidant system play an important role because their enzymatic components are involved in the regulation of free radical formation as well as degradation of LP product ${ }^{8-10}$. Burn conditions violate the homeostatic balance between active oxygen synthesis and antioxidant system functions ${ }^{5}$. The antioxidant activity of phenolic compounds occurs through various action mechanisms: inhibition of the active form of oxygen formation, singlet oxygen molecule neutralization, metal ion binding (as the reaction catalysts for the active oxygen forms), and interruption of the free radical reaction cascade during the LP processes ${ }^{11,12}$.

Analysis of modern literature has suggested possible promising means of lipid peroxidation normalization during first and second degree esophageal burns, in the case of natural origin substances, based 
on polyphenolic structure. These substances include melanin, a product of the yeast-like fungus Nadsoniella nigra strain $X-1{ }^{13}$. It is known that this drug exhibits antioxidant ${ }^{14-16}$, immunomodulatory ${ }^{17,18}$, anti-carcinogenic ${ }^{19}$ and stress-relieving ${ }^{20}$ properties, allowing it to be widely used in medicine. Therefore, the purpose of this work was to evaluate the peroxidation product content and activity changes in antioxidant system enzymes, e.g. superoxide dismutase (SOD) and catalase, in rat blood serum and tissues throughout different stages after an experimental burn infliction, with or without melanin treatment following burn injury.

\section{METHODS}

\section{Burn model of animals}

I our experiments, white wild rats (1 month old, 90$110 \mathrm{~g}$ in weight) were used in full compliance with provisions for the use of animals in biomedical experiments, as approved by the First Ukrainian National Congress on Bioethics (September 2001), as well as other international agreements and national legislation in the area. Chemical burns in animals were experimentally inflicted in the following way: alkaline esophageal burn (AEB) was induced using $20 \%$ sodium hydroxide $(\mathrm{NaOH})$. For this, the probe was injected into both an esophagus soldered at the end and a hole at a distance of $2 \mathrm{~mm}$ from it. The probe of $0.2 \mathrm{~mL}$ solution of $20 \% \mathrm{NaOH}$ was slowly injected for a depth of $4 \mathrm{~cm}$ from the rat's upper incision. This burn model corresponded to a $2^{\text {nd }}$ degree burn injury. Control rats were administered with the respective amount of water, injected orally once ${ }^{21}$. All animals in the study received a standard diet.

\section{Experimental groups}

The experimental scheme was as follows:

Group 1 - control, healthy rats (intact control);

Group 2 - rats bearing $2^{\text {nd }}$ degree AEB, administered with appropriate dose and timing of saline (burn control);

Group 3 - rats bearing $2^{\text {nd }}$ degree AEB, administered with melanin starting from the $2^{\text {nd }}$ day of the experiment at a dose of $1 \mathrm{mg} / \mathrm{kg}$ for 14 days.

\section{Treatment with melanin}

Producers of melanin used in our studies were the yeast like fungi Nadsoniella nigra strain X1 taken from the vertical rock samples from Antarctica island Galindez ${ }^{20}$.

\section{Sample collection}

Samples from the rats were collected at the $7^{t h}, 15^{t h}$ and $21^{\text {st }}$ day of the experiment, according to the stage of burn disease ${ }^{22}$. The method of sacrificing animals was cervical dislocation. The parameters that were evaluated were measured from serum, which was isolated by centrifugation of blood at $2000 \mathrm{~g} \times 40 \mathrm{~min}$, and from esophageal tissue.

\section{Determination of oxidative stress levels and antioxidant enzyme activities}

The TBK-active product content of was determined by Haryshvyly \& Stalnaya $(1977)^{23}$, while diene conjugate (DK) amount - by Gavrilov (1988) ${ }^{24}$. The enzyme activities were determined as follows: superoxide dismutase (SOD.KF 1.15.1.1) by the method described previously ${ }^{25}$; catalase (CAT, KF 1.11.1.9) by the method described previously ${ }^{26}$. The tissue protein content was estimated by the Lowry method ${ }^{27}$.

\section{Statistical analysis}

The experimental data were statistically analysed using Student's t-test; the significance level was set as $\mathrm{p}$ $<0.05$.

\section{RESULTS}

The body's antioxidant protection system controls and inhibits all phases of free radical reactions, from their initiation to the formation of hydroperoxides and TBK-active products. Therefore, in the first stage of our study, we determined the LPO intensity, measuring the level of TBK-active products and malondialdehyde (MDA) in rat blood serum and esophagus homogenate samples.

In our $2^{\text {nd }}$ degree AEB model, throughout the study, the concentration of TBK-active products in rat blood serum significantly increased by $30 \%, 54 \%$ and $40 \%$ after 7, 15 and 21 days, respectively, in comparison with the control values. Similar results were obtained in the esophageal tissues, where the TBK-active product concentration after $2^{\text {nd }}$ degree AEB increased by $204 \%, 131 \%$ and $25 \%$ after 7,15 and 21 days of our experiment, respectively, if compared to the control. When the drug melanin was administered, there was a tendency of the TBK-active product amount to decrease in rat blood serum by $31 \%$ at the $7^{\text {th }}$ day, by $32 \%$ at the $15^{\text {th }}$ day, and by $18 \%$ at the $21^{\text {st }}$ day. In the esophagus tissues, this decrease was decreased by $61 \%$ at the $7^{\text {th }}$ day, by $42 \%$ at the $15^{\text {th }}$ day and by $20 \%$ at the $21^{\text {st }}$ day of the experiments, respectively, when compared with animals bearing $2^{\text {nd }}$ degree AEB (Figure 1). 
A)

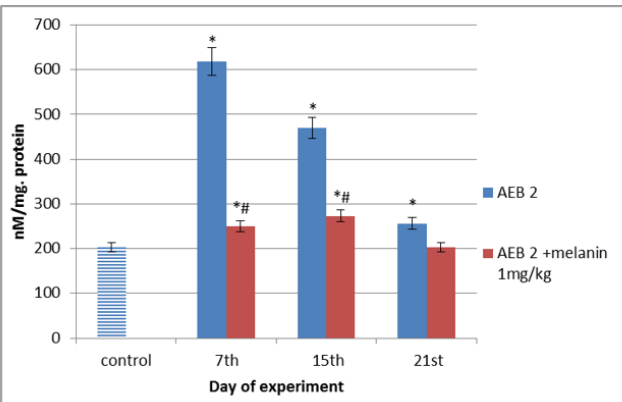

B)

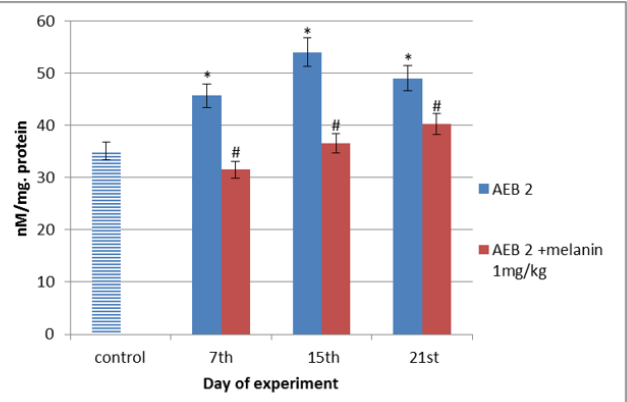

Figure 1: Concentration of TBK-active products in the esophagus tissues (A) and in the blood serum (B) of rats with induced second degree alkaline esophageal burns (AEB 2), with or without melanin treatment at a dose of $\mathbf{1} \mathbf{~ m g / k g}(\mathbf{M} \pm \mathbf{m}, \mathbf{n = 8}) .{ }^{*}$ - compared to the controls \#-compared to the $2^{\text {nd }}$ degree AEB (AEB 2)

A similar difference was also found in the esophagus tissues and rat blood serum when studying the process of lipid peroxidation and formation of the main end product, malondialdehyde (MDA), which is formed during primary and secondary lipid peroxidation product degradation. Indeed, for $2^{\text {nd }}$ degree AEB animals, the concentration of MDA in rat blood serum throughout the experiment was significantly increased by $246 \%, 387 \%$ and $556 \%$ at the $7^{t h}$, $15^{\text {th }}$ and $21^{\text {st }}$ day of experiment, respectively, in comparison with the controls. The results obtained in the esophagus tissues were somewhat similar, as the MDA concentration for AEB 2 increased by 357\%, 473\% and $589 \%$ at the $7^{t h}, 15^{\text {th }}$ and $21^{\text {st }}$ day of the experiment, respectively, when compared to the control. When the drug melanin was administered, it provoked the MDA content to decrease in both rat blood serum and esophagus tissue, especially after 15 and 21 days. In the serum, the MDA concentration was reduced by $43 \%$ and $62 \%$ at the $15^{t h}$ and $21^{\text {st }}$ day, when compared to the values for $2^{\text {nd }}$ degree AEB. In the esophagus tissues, the MDA amount was diminished by $57 \%$ at the $15^{\text {th }}$ day and by $82 \%$ at the $21^{\text {st }}$ day, in comparison to the $2^{\text {nd }}$ degree AEB values (Figure 2).

From analysis of the SOD activity in rat blood serum from animals with $2^{\text {nd }}$ degree AEB, it was observed that the enzyme activity of SOD decreased by $40 \%$ at the $7^{\text {th }}$ day, by $47 \%$ at the $15^{\text {th }}$ day and by $20 \%$ at the $21^{\text {st }}$ day of the experiment, in comparison with the control. In the study of the esophagus tissues, an increase in SOD activity by $11 \%$ was observed at the $7^{t h}$ day, which may be attributed to the body's compensatory response to burns, while at the $15^{\text {th }}$ day and $21^{\text {st }}$ day, SOD activity decreased by $33 \%$ and
$50 \%$, respectively, when compared to the control values. When the drug melanin was administered, there was an observed increase in the blood serum SOD activity by $33 \%$ at the $7^{\text {th }}$ day, by $63 \%$ at the $15^{\text {th }}$ day, and by $17 \%$ after the $21^{\text {st }}$ day, in comparison to the data obtained from rats with $2^{\text {nd }}$ degree AEB. In the esophageal tissues, under the action of melanin, this activity was increased by $33 \%$ at the $21^{\text {st }}$ day, when compared to the data obtained from the $2^{\text {nd }}$ degree AEB animals (Figure 3).

We showed that under the conditions of $2^{\text {nd }}$ degree $\mathrm{AEB}$, the catalase activity in rat blood serum increased throughout the experiment - by $106 \%$ at the $7^{\text {th }}$ day, by $153 \%$ at the $15^{\text {th }}$ day, and by $130 \%$ at the $21^{\text {st }}$ day, when compared to the control values. In the esophagus tissues, the activity of this enzyme was higher by $502 \%, 373 \%$ and $136 \%$ after 7,15 and 21 days, respectively, in comparison with the controls. Since hydrogen peroxide easily penetrates plasma membranes, catalase activation is more likely to increase in response to normal hydrogen peroxide levels in the esophageal tissues. With the introduction of the drug melanin, the catalase activity decreased in the esophagus by $52 \%$ at the $7^{\text {th }}$ day, by $37 \%$ at the $15^{\text {th }}$ day and by $19 \%$ at the $21^{\text {st }}$ day, when compared to the values from animals with $2^{\text {nd }}$ degree AEB. The growth of catalase activity may indicate that this enzyme has an active organism LPO resistance in the organism in the processes after chemical burn infliction (Figure 4). Therefore, with $2^{\text {nd }}$ degree esophagus burns on the background of increased LOP activity, we demonstrated the significant inhibition of antioxidant defense mechanisms. Under the conditions of burn disease, a disturbance of the balance between the prooxidant factor activity and the antioxidant system activity may be present due to the intensification of the 
A)

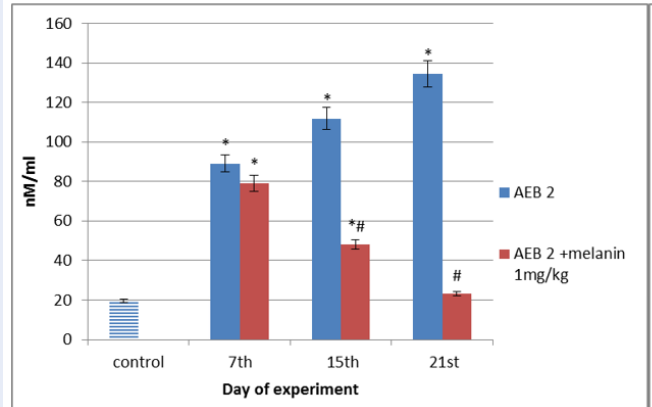

B)

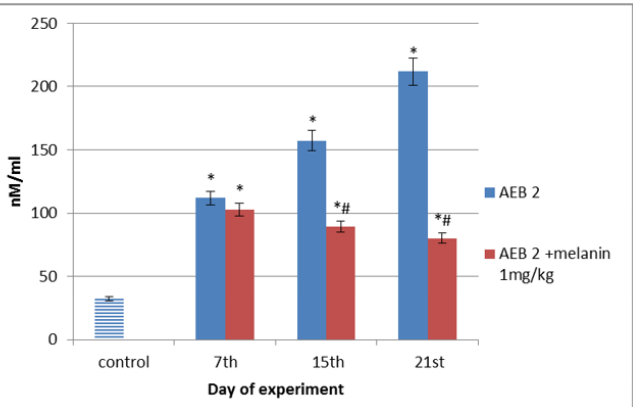

Figure 2: The malondialdehyde (MA) content in the tissues of the esophagus (A) and in the blood serum (B) of rats with induced second degree alkaline esophageal burns (AEB 2), with or without melanin treatmentat a dose of $\mathbf{1} \mathbf{~ m g} / \mathbf{k g}(\mathbf{M} \pm \mathbf{m}, \mathbf{n}=\mathbf{8})$. ${ }^{*}$ - compared to the controls \# - compared to the $2^{\text {nd }}$ degree AEB (AEB 2)

A)

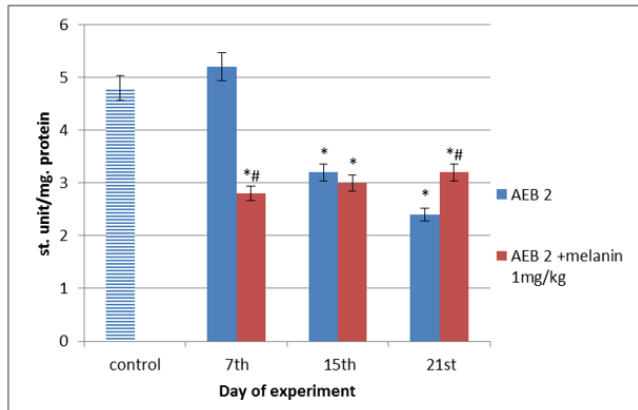

B)

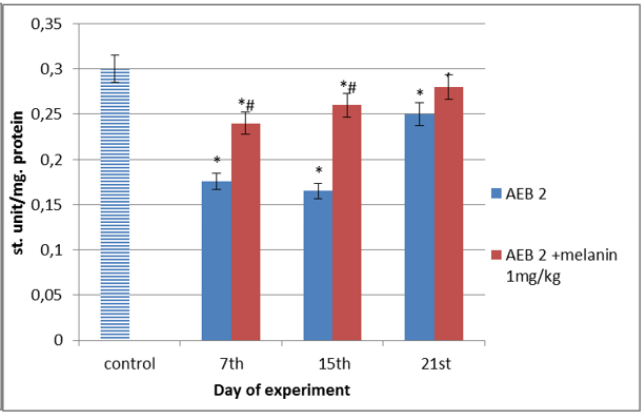

Figure 3: The SOD activity in the tissues of the esophagus (A) and in the blood serum (B) of rats with induced second degree alkaline esophageal burns (AEB 2), with or without melanin treatment at a dose of $\mathbf{1 ~} \mathbf{m g} / \mathbf{k g}$ ( $\mathbf{M} \pm \mathbf{m}, \mathbf{n}=\mathbf{8}) .{ }^{*}$ - compared to the controls \# - compared to the $2^{\text {nd }}$ degree AEB (AEB 2)

A)

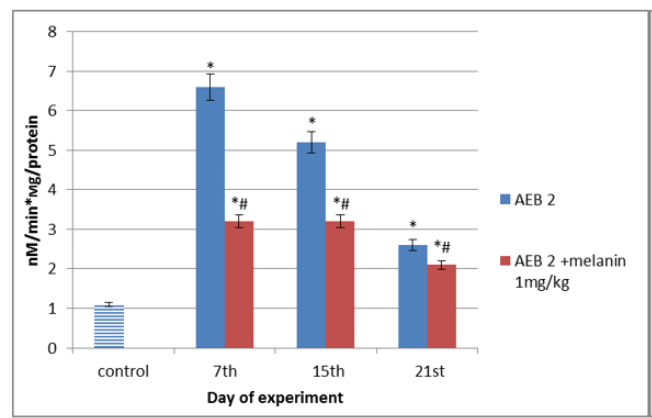

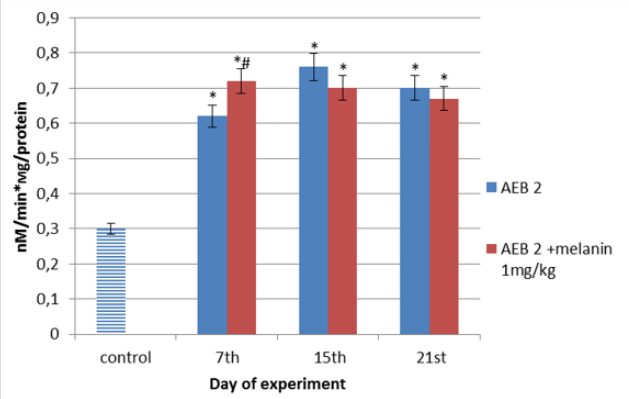

Figure 4: The catalase activity in the tissues of the esophagus (A) and in the blood serum (B) of rats with induced second degree alkaline esophageal burns(AEB 2), with or without melanin treatment at a dose of $\mathbf{1} \mathbf{~ m g} / \mathbf{k g}(\mathbf{M} \pm \mathbf{m}, \mathbf{n}=\mathbf{8}) .{ }^{*}$ - compared to the controls \# - compared to the $2^{\text {nd }}$ degree $A E B(A E B$ 2) 
free radical conversion process. It was established that the evaluated system activity changes, in the case of AEB, depend on the stage of burn disease. The highest amount of TBK-active products was observed at toxemia (7 day) and septicotoxemia (15 day) stages. The greatest increase in the MDA level was evident in the blood and esophagus tissues at the $15^{\text {th }}$ and $21^{\text {st }}$ days. There was also a decrease in SOD activity and increase in catalase activity. Finally, it was shown that the use of melanin significantly contributes to the reduction of peroxide oxidation product content (MDA, TBKactive products), as well as contributing to SOD activity increase and catalase activity decrease.

\section{DISCUSSION}

In this study, the antioxidant property of melanin was studied in an alkaline esophageal burn model. Our results suggest that melanin is an inhibitor of lipid peroxide oxidation.

Active forms of oxygen (AFO) hyper-production, being one of the main pathological factors, induces the literal "avalanche" of uncontrolled AFO synthesis the process of a huge potential danger for any cell and tissue. One of the decisive factors in damaged epithelium regeneration is the oxidant-antioxidant balance restoration speed. This process can be aided effectively using various antioxidants. The radicals of hydroxyl and superoxide anion are two types of the most important free radicals in whole organisms. The production of hydroxyl radicals plays a significant role in the initiation of lipid peroxidation ${ }^{28}$. Membrane lipids are particularly susceptible to oxidation due to the high concentration of polyunsaturated fatty acids and their association with enzymatic and nonenzymatic systems in the cell membrane is capable of generating free molecules of radicals ${ }^{29}$.

The oxidative modification of cellular structures and enzymes appears to be one of their destruction mechanisms leading to the subsequent molecular component upgrade. The process of radical oxidation is associated with protein lipid, nucleic acids, prostaglandin and other substance turnover in cells. Antioxidant system exhaustion usually become a major factor of pathogenesis for a considerable number of diseases.

Normally free radical processes play an important role in biological system functioning by participating in complex reaction sets aimed for regulation of cellular metabolism. In addition, free radical reactions are considered to be the universal mechanism of cell damage inflicted by various factors ${ }^{30}$. Thus, their excessive activation plays a key role in cell damage, being able to stimulate both cell defense mechanisms and proliferation. The excessive accumulation of LP products in an organism occurs mainly in a form of highly toxic superoxide anion-radicals, which can lead to significant organism disorders and severe endotoxicosis.

Tissue and serum content of MDA and TBK-active products (the final product of lipid breakdown caused by oxidative stress) are considered to be good indicators for radical-induced lipid peroxidation ${ }^{31,32}$. After burning, the content of lipid peroxide oxidation increased. In the application of melanin, there was a decrease in the content of the studied parameters, which may indicate the inhibition of lipid peroxidation by melanin.

Burn disease intensifies active oxygen form synthesis which can lead to prominent tissue damage. In this case, an unbalance between the intensity of the free radical formation process and the antioxidant system activity levels may be issued, resulting in biomolecule oxidation speed increases. Disturbances in the normal course of oxidative processes underlying cell metabolism and determining organism overall adaptive capacity leads to the oxidative stress forma$\operatorname{tion}^{33}$. It is a major metabolic syndrome that promotes the development of numerous organism morphofunctional disorders ${ }^{34}$.

An excessive amount of ROS can react with many bio-molecules, such as DNA ${ }^{35}$, lipids ${ }^{36}$, or proteins ${ }^{37}$. Our body has several enzymes that play an important role in removing excess ROS in the cell. Enzymes such as SOD and CAT are most important in the cellular antioxidant system ${ }^{38,39}$.

Superoxide dismutase (SOD) and catalase are the major enzymes of antioxidant cell defense. The activity of these enzymes determines cell resistance to oxidative stress consequences. Changes in the activity of SOD and catalase appear to be an indicator of formed primary product amounts in reactions of superoxide ion-radical oxidation as well as a number of its further transformation products. Therefore, in order to evaluate free radical processes activity in the tissues of both the esophagus and the rat blood serum, we studied the activity of the following enzyme components of the antioxidant system - catalase and SOD.

Superoxide dismutase is an enzyme belonging to a group of antioxidant enzymes protecting an organism from highly toxic oxygen radicals. SOD catalyzes superoxide dismutation into oxygen and hydrogen peroxide and is present in all cells able to absorb oxygen. Superoxide dismutase activity suppression usually leads to superoxide anion-radical accumulation, initiating chains of free radical reactions in 
cells. Therefore, the established SOD activity dynamics, as well as the LP final product concentration, may indicate free radical oxidation process activation ${ }^{40}$. In systemic metabolic disorder development inflicted by burns of mild and moderate severity, free radical lipid oxidation plays an important role in the case of both enzymatic and non-enzymatic antioxidant system activity and their insufficient levels in blood $^{29}$. The increase of free radical synthesis activity in such pathological conditions leads to prooxidantantioxidant balance disturbance and, as an effect, oxidative stress development.

Catalase (hydrogen peroxide: hydrogen peroxide oxidoreductase, 1.11.1.6.) is an enzyme of the oxidoreductase class found in almost all eukaryotic organism tissues. It carries out the reaction of reducing hydrogen peroxide to water and oxygen using various proton donors. SOD and catalase act as synergistic enzymes. Thus, in the process of the SOD reaction, hydrogen peroxide is formed, for which the destruction of a catalase is required. If catalase activity is diminished, hydrogen peroxide can act as a SOD inhibitor ${ }^{41}$. Therefore, correct and sufficient mutual activities of these two enzymes are very important for maintaining the cell oxidant-antioxidant balance.

As it is known, the increased number of active forms of oxygen can be caused by the activation of neutrophils, which in turn can be activated by interleukins. Peroxisol proliferation activation receptors (PPARs) are considered one of such molecular links between pro-inflammatory cytokines and transcription factors. The earlier studies indicate that the effect of melanin may be mediated by interaction or partial interaction with receptors ${ }^{42}$.

Therefore, it was interesting to investigate the activity of these enzymes under conditions of chemical burn and also under conditions of application of melanina as treatment. At the burn, the activity of SOD is significantly decreased and catalase activity is increased in blood and esophageal tissues. elanin increased the enzymatic activity of SOD and decreased the activity of catalase (Figures 3 and 4). This may be responsible for increased resistance to oxidative stress. As shown in Figure 4C, the activity of catalase in the blood serum and tissues of the esophagus was significantly increased after burns, these data may be due to an instinctive protective effect in response of oxidative stress.

\section{CONCLUSIONS}

To our knowledge, this is the first study to demonstrate the antioxidant property of melanin in an alkaline burn model of the esophagus. The study herein showed that melanin reduced the content of lipid peroxide oxidation products and normalized antioxidant enzyme activity after induction of alkaline esophageal burn. The data obtained in the study indicate that there is a possible prospect for the use of melanin in the future for treating chemical burns of the esophagus.

\section{COMPETING INTERESTS}

No conflict of interest to declare.

\section{Authors' Contributions}

Natalia Chornenka: planning an experiment, carrying out of experimental researches, calculation of results. Yana Raetska: planning an experiment, analysis of results, carrying out of experimental researches. Dmitro Grebinyk: preparation of the article for printing, calculation of results. Alevtina Dranitsina: carrying out of experimental researches, calculation of results. Olexiy Savchuk: planning an experiment, analysis of results, carrying out of experimental researches. Tetiana Beregova: preparation of the article for printing. Ludmila Ostapchenko: planning an experiment, analysis of results

\section{ACKNOWLEDGMENTS}

We would like to appreciation Professor Tatiana Beregova, Ph.D., for kindly providing the melanin reagent for our research.

\section{ABBREVIATIONS}

AEB: alkaline esophageal burn

AFO: active forms of oxygen

AOD: antioxidant defense

CAT: catalase

DK: diene conjugate

LP: lipid peroxide

LPO: lipid peroxide oxidation

MDA: malondialdehyde

PPARs: peroxisol proliferation activation receptors SOD: superoxide dismutase

\section{REFERENCES}

1. Chipp E, Charles L, Thomas C, Whiting K, Moiemen N, Wilson Y. A prospective study of time to healing and hypertrophic scarring in paediatric burns: every day counts. Burns and Trauma. 2017;5:3. Available from: DOI:10.1186/s41038-016-0068-2.

2. Chipp E, Milner CS, Blackburn AV. Sepsis in burns: a review of current practice and future therapies. Annals of Plastic Surgery. 2010;65:228-36. Available from: DOI:10.1097/SAP. 0b013e3181c9c35c.

3. Alnababtah K, Khan S, Ashford R. Socio-demographic factors and the prevalence of burns in children: an overview of the literature. Paediatrics and International Child Health. 2016;36:45-51. Available from: Doi:10.1179/2046905514y. 0000000157. 
4. Jun WH, Jie X, Jun Z, Feng T, Hui HG. Comparable results of epidemiology of children with burns among different decades in a burn unit in JinZhou, China. Burns. 2011;37:513-20. Available from: DOI:10.1016/j.burns.2010.11.001.

5. Netyukhailo LG, Sukhomlin TA, Basarab YA, Bondarenko VV, Kharchenko SV. The state of the antioxidant system of the internal organs in rats during burn disease. BûlletenŚibirskoj Mediciny. 2014;13:51-5.

6. Parihar A, Parihar MS, Milner S, Bhat S. Oxidative stress and anti-oxidative mobilization in burn injury. Burns. 2008;34:617. Available from: DOI:10.1016/j.burns.2007.04.009.

7. G NL, v. Reactive oxygen. Young Scientist. 2014;9(12).

8. Kharchenko SV KANL. Pathogenesis of the burn disease. Svit medicini ta biologiyi. 2011;1.

9. Varkholyak IS GZILPOMSGBGDLY Martyschuk TV. The biological significance of the antioxidant defense system of animals body. Scientific Messenger LNUVMBT named after SZ Gzhytskyj. 2016;18:66.

10. NV K, RG S, MM A. Aktyvnisténzymiv antyoksydantnogo zahystu $v$ reproduktyvnyh organah koriv za normy ta patologii. Nauk visnyk LNUVMBT im SZ Gźhyc囚ogo Lv区®. 2014;2:3-9. null.

11. Carletti G, Nervo G, Cattivelli L. Flavonoids and Melanins: a common strategy across two kingdoms. International Journal of Biological Sciences. 2014;10:1159-70. Available from: DOI: 10.7150/ijbs.9672.

12. Pourcel L, Routaboul JM, Cheynier V, Lepiniec L, Debeaujon I. Flavonoid oxidation in plants: from biochemical properties to physiological functions. Trends in Plant Science. 2007;12:2936. Available from: DOI:10.1016/j.tplants.2006.11.006

13. Tsyryuk OI BTCN. The level of cortisol in the blood of rats before and after stress action against the background of melanin. Visnik of problems of biology and medicine. 2007;p. 40-4.

14. Brenner $\mathrm{M}$, Hearing $\mathrm{VJ}$. The protective role of melanin against UV damage in human skin. Photochemistry and Photobiology. 2008;84:539-49. Available from: DOI:10.1111/j.17511097.2007.00226.x.

15. Tashirev AB CNRV Shilin SO. Resistance to UV radiation of microorganisms isolated from the rock biotopes of the Antarctic region. Mikrobiolohichnyi zhurnal (Kiev, Ukraine: 1993). 2010;72:8-13.

16. Keypour S, Riahi H, Moradali M, Rafati $H$. Investigation of the antibacterial activity of a chloroform extract of Ling Zhi or Reishi medicinal mushroom, Ganoderma lucidum (W. Curt:: Fr.) P. Karst. (Aphyllophoromycetideae), from Iran. International Journal of Medicinal Mushrooms. 2008;10:345-9. Available from: DOI:10.1615/IntJMedMushr.v10.14.70.

17. Racca S, Spaccamiglio A, Esculapio $P$, Abbadessa G, Cangemi L, DiCarlo F. Effects of swim stress and alpha-MSH acute pre-treatment on brain 5-HT transporter and corticosterone receptor. Pharmacology, Biochemistry, and Behavior. 2005;81:894-900. Available from: DOI:10.1016/j.pbb.2005.06 014.

18. Chornenka NM, Raetska YA, Savchuk OM, Torgalo EO, Beregova TV, Ostapchenko LI. Correction Parameters of Endogenous Intoxication in Experimental Burn Disease at the Stage of Toxemia. Research Journal Of Pharmaceutical Biological And Chemical Sciences. 2016;7:1042.

19. Seniuk O, Gorovoj L, Kovalev V. Anticancerogenic propertis of melaninglucan complex from higher fungi. In: Proc. 5th Internat. Med. Mushroom Con., 5th-8th September, 2009, Nantong. vol. 2009. Nantong, China; 2009. p. 142-9.

20. Falalyeyeva TM BTOLGD Chyzhanska NV. White blood count of rats under stress-induced stomach lesions and the prophylactic administration of melanin. Ukrainian Antarctic Journal. 2015;p. 114

21. Raetska YB, Ishchuk TV, Savchuk OM, Ostapchenko LI. Experimental modeling of first-degree chemically-induced esophageal burns in rats. Medicinal Chemistry (Shariqah, United Arab Emirates). 2013;15:30-4.
22. Fistal EY, Kozinets GP, Samoilenko GE, al. G.E Samoilenko and al. In: Combustiology. Kharkov; 2004. p. 184. null.

23. Haryshvyly TG, Stalnaya YD. Sovremennye metody v biokhimii; 1977. null.

24. Gavrilov VB. Izmerenie dienovykh conyugatov v plasme krovi po UF poglosheniyu geptanovykh i izopropanolnykh ekstractov / V.B. Gavrilov, A.R. Gavrilov, N.F. Khmara. Laboratornoe Delo. 1988;2:60-3.

25. VA K, AI P, Zhl K. prostoy i chuvstvitelnyy metod opredeleniya SOD, osnovannyy na reaktsiy okisleniya kvertsetina. Voprosy medetsinskoy khimiy. 1990;2:88-91. null.

26. A KM. Metod opredeleniya activnosti katalazy $v$ biologicheskom materiale / M.A. Koroliuk. In: Koroliuk MA, editor. Laboratory work. vol. 2; 1988. p. 31-4.

27. Lowry OH, Rosebrough NJ, Farr AL, Randall RJ. Protein measurement with the Folin phenol reagent. Journal of biological chemistry. 1951;193(1):265-275.

28. Yang X, Bai H, Cai W, Li J, Zhou Q, Wang Y. Lycium barbarum polysaccharides reduce intestinal ischemia/reperfusion injuries in rats. Chemico-Biological Interactions. 2013:204:16672. Available from: DOI:10.1016/j.cbi.2013.05.010.

29. Aruoma Ol. Free radicals, oxidative stress, and antioxidants in human health and disease. Journal of the American Oil ChemistsŚociety. 1998;75:199-212. Available from: DOI:10 1007/s11746-998-0032-9.

30. Chesnokova NP. Aktivaciya svobodnoradikalnogo okisleniya efferentnoe zveno tipovyh patologicheskih processov - Saratov. Izd-vo SMU. 2006;p. 177.

31. Wang X, Hai CX, Liang X, Yu SX, Zhang W, Li YL. The protective effects of Acanthopanax senticosus Harms aqueous extracts against oxidative stress: role of $\mathrm{Nrf2}$ and antioxidant enzymes. Journal of Ethnopharmacology. 2010;127:424-32. Available from: DOI:10.1016/j.jep.2009.10.022.

32. Sato $Y$, Itagaki S, Oikawa S, Ogura J, Kobayashi M, Hirano T. Protective effect of soy isoflavone genistein on ischemiareperfusion in the rat small intestine. Biological \& Pharmaceutical Bulletin. 2011;34:1448-54. Available from: DOI:10.1248/ bpb.34.1448.

33. Piterskaya YUA LVME. Aktivnost antioksidantnyh fermentov $\checkmark$ rane pri glubokih ozhogah. Byulleten eksperimentalnoj biologii i mediciny. 2009;147:696-699.

34. RKFIA. Svobodnoradikalnoe okislenie v tkanyah tonkoj kishki, legkih i pecheni pri ozhogovom shoke. Medicinskij vestnik Bashkortostana. 2009;4:113-115.

35. Marnett LJ. Oxyradicals and DNA damage. Carcinogenesis. 2000;21:361-70. Available from: DOI:10.1093/carcin/21.3.361.

36. Ylä-Herttuala S. Oxidized LDL and atherogenesis. Annals of the New York Academy of Sciences. 1999;874:134-7. Available from: DOI:10.1111/j.1749-6632.1999.tb09231.x.

37. Stadtman ER, Levine RL. Protein oxidation. Annals of the New York Academy of Sciences. 2000;899:191-208. Available from DOI:10.1111/j.1749-6632.2000.tb06187.x.

38. Wang X, Ye XL, Liu R, Chen HL, Bai H, Liang X. Antioxidant activities of oleanolic acid in vitro: possible role of $\mathrm{Nrf} 2$ and MAP kinases. Chemico-Biological Interactions. 2010;184:32837. Available from: DOI:10.1016/j.cbi.2010.01.034.

39. Yang X, Bai H, Cai W, Li J, Zhou Q, Wang Y. Lycium barbarum polysaccharides reduce intestinal ischemia/reperfusion injuries in rats. Chemico-Biological Interactions. 2013;204:16672. Available from: DOI:10.1016/j.cbi.2013.05.010.

40. MR AHD. Lipid peroxidation and antioxidant system enzyme activity in rat lung under long term administration of aflatoxin b1. Biooi sc Tap. 2012;14:1-2.

41. Abdel-Wahhab MA, Abdel-Galil MM, El-Lithey M. Melatonin counteracts oxidative stress in rats fed an ochratoxin A contaminated diet. Journal of Pineal Research. 2005;38:130-5. Available from: DOI:10.1111/j.1600-079X.2004.00184.x.

42. Kukharskyy M TOKV Chyizhanska NV. The involvement of peroxisome proliferator-activated receptors gamma in antiulcer action of melanin. Ukrainian antarctic jornal. 2009;8:374-376.

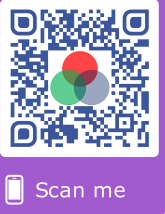

